\title{
Role of Political Education in Improving Public Participation in Election: The Case ofWest Sumatera Governor Election
}

\author{
Pebriyenni $^{* 1}$, Azwar Ananda ${ }^{2}$, Nurhizrah Gistituati ${ }^{3}$ \\ ${ }^{1}$ Department of Civic Education, Universitas Bung Hatta, West Sumatra- Indonesia \\ ${ }^{2}$ Department of Civic Education, Universitas Negeri Padang, West Sumatra- Indonesia \\ ${ }^{3}$ Department of Education Administration, Universitas Negeri Padang, West Sumatra-Indonesia \\ *Corresponding author E-mail: pebriyenni@bunghatta.ac.id
}

\begin{abstract}
This article describes the role of political education to improve public participation in the election of West Sumatra governor. The governor election is expected to be able to raise the level ofoptimism in order to improve the leadership qualities of local government, and the spirit of political education for citizen. This study applied descriptive qualitative method by using interviews and documentations as research instruments. Based on the documentation instrument, it showed the statistics of permanent voters who voted in the 2015 for governor election was $59.58 \%$ or $3,489,743$ permanent voters. It was implied that $40.42 \%$ or $1,410,680$ voters did not take their votes. This low level of public participation could be a sign that democracy has not effectively been implemented at the local level. The researchers concluded that the socialization activities of Governor election, as one of responsibilities of General Election Commission, have failed to increase the political awareness of the society.
\end{abstract}

Keywords: Political Education, Public Participation, Socialization

\section{Introduction}

According to Indonesia Election Law as stated in 1945 Constitution of The Republic of Indonesia, Section VIIB Article 22e (5),"The general elections shall be organized by a general election commission that shall be national, permanent and independent in nature"(Amandement of 1945 Constitution of The Republic of Indonesia, 2002). The implementation of the public elections at the provincial level is established by the provincial commission which is assigned to organize the election of the Governor and Vice Governor. A right process of the Governor and Vice Governor election cannot be merely seen by the workings of the General Election Commission, but it must be followed by the public awareness and participation. The rate of public participation is influenced by how the Provincial General Election Commission leads the society, which gives affect to the results of the governor election. Guided by the prevailing laws, West Sumatra has conducted the direct election of governor in 2015. The results of the election are showed in Table 1.

Table 1: Summary of Voters Recapitulation Results in the Governor Election of West Sumatra 2015

\begin{tabular}{|r|l|r|r|r|r|r|}
\hline \multirow{2}{*}{ No. } & \multirow{2}{*}{ City/District } & \multirow{2}{*}{$\begin{array}{c}\text { No. of } \\
\text { Voters }\end{array}$} & \multicolumn{2}{|c|}{ Use Vote } & \multicolumn{2}{c|}{ No Vote } \\
\cline { 5 - 7 } & & Amount & \multicolumn{1}{c|}{$\%$} & \multicolumn{1}{c|}{ Amount } & \multicolumn{1}{c|}{$\%$} \\
\hline 1 & Agam & 331.785 & 183.128 & 55.19 & 148,657 & 44.81 \\
\hline 2 & Dharmas Raya & 133.502 & 99.752 & 74.2 & 33,750 & 25.28 \\
\hline 3 & $\begin{array}{l}\text { Kepulauan } \\
\text { Mentawai }\end{array}$ & 54.231 & 34.719 & 64,02 & 19,512 & 35.98 \\
\hline 4 & & & & & \\
\hline 5 & Pukit Tinggi & 72.450 & 43.843 & 60.51 & 28,607 & 39.49 \\
\hline 6 & Padang & 548,213 & 290.189 & 52.93 & 258,024 & 47.07 \\
\hline 7 & Pariaman & 35.751 & 16.765 & 46.89 & 18,986 & 53.11 \\
\hline 8 & Payakumbuh & 86.057 & 31.636 & 53.56 & 27,427 & 46.44 \\
\hline
\end{tabular}

\begin{tabular}{|r|l|r|r|r|r|r|}
\hline 9 & Sawahlunto & 43.248 & 23.057 & 53.31 & 20,191 & 46.69 \\
\hline 10 & Solok City & 44.650 & 32.469 & 72.72 & 12,181 & 27.28 \\
\hline 11 & $\begin{array}{l}\text { Lima Puluh } \\
\text { Kota }\end{array}$ & 262.738 & 161.250 & 61.37 & 101,488 & 38.63 \\
\hline 12 & $\begin{array}{l}\text { Padang Pari- } \\
\text { aman }\end{array}$ & 275.845 & 150.546 & 54.58 & 125,299 & 45.42 \\
\hline 13 & Pasaman & 186.760 & 133,082 & 71.26 & 53,678 & 28.74 \\
\hline 14 & Pasaman Barat & 248.154 & 160.578 & 64.71 & 87,576 & 35.29 \\
\hline 15 & Pesisir Selatan & 310.548 & 203.221 & 65.44 & 107,327 & 34.57 \\
\hline 16 & Sijunjung & 147.946 & 88.007 & 59.49 & 59,939 & 40.51 \\
\hline 17 & Solok District & 271.474 & 155.897 & 57.43 & 115,577 & 42.57 \\
\hline 18 & Solok Selatan & 110.151 & 76.918 & 69.83 & 33,233 & 30.17 \\
\hline 19 & Tanah Datar & 266.507 & 149.090 & 55.94 & 117,417 & 44.06 \\
\hline \multicolumn{2}{|c|}{ Total } & $\mathbf{3 . 4 8 9 . 7 4 3}$ & $\mathbf{2 . 0 7 9 . 0 6 3}$ & $\mathbf{5 9 . 5 8}$ & $\mathbf{1 , 4 1 0 , 6 8 0}$ & $\mathbf{4 0 . 4 2}$ \\
\hline
\end{tabular}

Source: The General Election Commission of West Sumatra Province Indonesia (2015)

Based on Table 1 above, $40.42 \%$ population of West Sumatera chose not to vote. The low public participation of West Sumatra in governor election indicates a problem. The low turnout could be due to other issues related to the election of West Sumatra Governor including; delaying in budget realization, increasing apathetic voters, attacking, non-functioning political apparatus (political parties and volunteers didnot work maximally) and questioning the quality of candidates (1). Ferree et al.(2) explored the relation of individual vote choice, the credibility and quality of the election process by evaluating voters, irregularities in the management of the election and the vote count.

In addition, Fortin-Rittberger (3), described different causes of electoral fraud, for example; voter and candidate intimidation, fraudulent tabulation of votes, unfair media coverage of campaigns and vote-buying. The level of political awareness in community influences the success of the governor election. This level was reflected by how many participations that the society give in the process of election (4). Political education is the 
process of learning and understanding the rights, obligations and responsibilities of every citizen in the life of nation and state. The General Election Commissions and the political parties are responsible for providing political education for community. It was in line with the scope of their responsibilities with due regard to equity and gender equality with the aim of: a) To raise awareness of the rights and obligations of the people in community, nation and state; b) To Increase political participation and community initiatives in the life of society, nation, and state; c) To increase independence, maturity, and the character building of the nation in order to maintain unity of the nation; and d) To build ethics and political culture in the basis of Pancasila (nasional principle).

\section{Literature Review}

Democracy and elections are intrinsically connected, because democracy is built by elections. In order to establish democratic governments, electorates use their individual right by giving votes for their preferred political parties, which compete to rule in their countries (5). Many literature studies have listed various reasons or motives for electoral rigging. Ballot fraud is usually possible to do easily or conveniently because the incumbent could control the way that elections are run, for instance, through electoral commissions, (6).

Electoral manipulation is conducted to increase the margins of victory in asymmetrical races in order to weaken opposition parties from forming and running, and to put voters off from supporting the incumbents' opponents (3). Lehoucq (7), has discovered that election fraud lies from procedural violations of electoral law to the outright use of violence to intimidate voters and poll-watchers. He outlined how there were many reasons behind electoral rigging, such as social inequality and political competitiveness. By using journalistic evidence and historical research, (8) analyzed electoral competition based on ideological and conflictual reasons. He also continued that if the electoral competition is based on ethnic and religious reasons, then the elections will be more violent

\section{Learning Theories}

Learning theories give guidelines to enhance instruction (9-10) Cognitivists specialize in mechanisms by that the mind stores, processes and recovers data information (9,11-12). McLeod (13) stated that a cognitivist views the learning process as an internal and active mental process, which develops within a learner, increased mental capacity and skills in order to learn better. Engaging instruction is meant to ask learners' attention and to motivate active participation. Allen stated that Cognitivists means that learning opportunities ought to involve opportunities for learners to be actively concerned within the process; now and then developing their own goals and activities. Allen (14). According to Yilmaz, cognitivism focuses on "what learners grasp and the way they are available to accumulate it than what they do" (15). The emphasis in cognitivism is mostly on acquiring, processing and assimilating knowledge. The emphasis in cognitivism is generally on effort, process and absorptive information. Constructivists believe that the creation of knowledgeincludesboth mental effort and social interaction(16).

Constructivism mirrors the view that guideline ought to urge students to build importance bringing about upgraded learning $(9,16-17)$. It is underlined that obviously the focal point of constructivism is on making intellectual devices which mirror the shrewdness of the way of life in which they are utilized and additionally the bits of knowledge and encounters of people.It is vital to take note of that, while powerful guideline and substance introduction abilities are imperative, successful learning cannot happen without members' (i.e. voters) endeavors and ability to learn and apply the ideas (18-20). Fundamentally, powerful instructional practices ought to be coordinated with similarly great understudy inspiration for advancing learning. A instructor can give data and encourage exchanges, yet a student needs to comprehend the substance (21-22).

\section{Model of Political Education}

In 2014, there are over a million people in the United Kingdom who have a learning disability and can vote but don't - not because they did not want to but because the system excluded them. They have been turned away from polling stations. Access to voting for those who have learning disability weredifficult. The form to register the election was not easily accessible, manifestos were very difficult to read and it is hard to get the support to speak to local candidates. This election has been pushed through so quickly that parties haven't had the time to prepare resources which would make voting for people with learning disabilities possible.

In order to solve these problems, two political education programs were implemented to increase the participation of disabilities, namely Me and My Vote and Hear My Voice campaign. The projects aimed to have interaction folks with a learning disorder within the democratic method, encouraging them to register to vote and successively vote either by post or at the ballot box within the 2015 election

These projects were initiated by Mencap - Mencap Trust Company Ltd is an independent, not-for-profit, discretionary trust service, set up by Mencap more than 40 years ago to help valuing and supporting community with a learning disability, and their families and carers. Because the leading voice of learning disability, Mencap, at the side of the electoral commission, developed associate degreed distributed an "easy reading pack" to Mencap services, native teams and partners also as on to community with a learning disability, their families and carers. The pack filled of easy to understand materials concerning the democratic method, the way to register and to vote. Local teams and partners received coaching on the way to use the pack either with people or within the context of delivering a group workshop.

Furthermore, an awareness raising campaign and marketing strategy was implemented and electoral registration activity was embedded at intervals Mencap's core care services. All of information and materials from "Me and My Vote" succeeded in reaching over 35,000 citizens across England. Aside from "Me and My Vote", Mencap ran the "Hear My Voice" campaign, the main focus of that was empowering individuals with a learning disability and their families to have interaction directly with their candidates within the start to the final election. The campaign was greatly a platform for people to inform their story on to candidates who needed to represent them in parliament. To create this platform, Mencap launched a great website wherever people might share their stories (which successively were mechanically emailed to local candidates from all parties) (www.hear-myvoice.org.uk). The candidates were reciprocally inspired to pledge to mention "I'm listening". This was exceptionally booming with 2,373 people sharing their stories and 832 candidates pledging support. In total, 151 of the candidates went on to become elective MPs, together with government ministers and shadow ministers (23).

\section{Methods}

According to the problems stated above, this study used descriptive research method to investigate the circumstances, conditions, situations, events, and activities. The results of research are described in the form of reports. This research was conducted on March and April 2018. The unit of analysis was the staff of the Provincial General Election Commission of West Sumatra Province. Data were collected based on the interviews to five respondents using a documentation instrument records. Data analyses started with the preparation and organization of the data, explora- 
tion and codification of the data, representation of the qualitative findings and interpretation and validation of the accuracy of the findings. The data analysis was the process of assembling and finding the data that were obtained by interviews, documentations, and other materials systematically.

\section{Results and Discussion}

West Sumatra province has 12 districts and 7 cities with a population about $5,389,418$ people which is divided into $2,730,005$ men and $2,659,363$ women, yet the number of voters is $3,489,743$ people. The governor election was conducted by the general election commission of province in three stages: preparation, implementation and evaluation. In the preparation phase, the election commission was planning the implementation of the governor's election day. The major planning was the budget and technical guidance regarding the procedures for voting and counting as well as logistics. The results of interviews conducted with respondent A showed that the planning was done well before the election. Respondents noted that the problems that occurred at the preparation stage wasthe delay of realization and distribution of the general election budget.

At the implementation stage, interviews with respondent $\mathrm{B}$ was done by assessing the implementation of the general election. The general election commission cooperated with documentation on the election supervisory, local government, police, political parties, media and civil society organizations. The researchers performed the following: [1] calculated the voting results, [2] recapitulated the election votes, [3] launched an inference, [4] wrotepress release for the constitutional court, [5] waited for the court judgement [6] concluded the chosen candidate.

Political education is an important factor to improve the quality of political participation of voters. Political education can increase knowledge about the developing political dynamics. Results of interviews with respondent A stated that "We do politics in the public education that outreach the schools. It is considered necessary given the current right to vote entirely in the hands of the people". Respondent B explained that through political education, the public can understand the values of the political system, citizens have the knowledge, attitudes and skills of politics, especially during elections. In line with this, respondent $\mathrm{D}$ explained "in general, political education is the process of planning a political value deliberated and planned, both formal and informal continuously from generation to generation." Political education is an effort to improve and strengthen the political consciousness. Political education should be carried out on an ongoing basis so that people can continue to improve their understanding of the political world. This answer was in the line with what respondent $\mathrm{C}$ said, through a process of political education of community members, it could determine the attitude and orientation towards political life. These were the political education as the process of learning and understanding the rights, obligations and responsibilities of every citizen in Indonesia. Political education in this regard could be formedas practicing, teaching, and counselling to develop the capacity and potency of society. Political education was done through a process of dialogical voluntary between the giver and the recipient regularly. So, the recipient of a message could have an awareness of democracy.

According to the findings of the research results of interviews with respondents $\mathrm{E}$, the materials for political education consisted of the components of state politics, nationalism, rights and obligations, the system of government and elections, especially related to electoral few teaching materials available such as booklets, leaflets, flyers, and video. Various aspects needed to be communicated to the public related to the election, for example the benefits of elections, the names of the participants of the election, a call to vote, the procedure for the election, the election schedule, especially at the stage of the campaign, the procedure of voting, the schedule of voting and announcement of results counting.
Messages in socialization to the community needed to be done in an interesting, informative, simple, and easy to understand. Media socialization could be done in the form of simulated voting, or by placing public service announcements in print and electronic media, outdoor advertising (outdoors) with banners and billboards in strategic places, distribution of brochures, stickers, and so forth. As afacility of political education, the general election commissions of West Sumatra province had the smart house election. Smart home has become a facility of political education to boost voter participation, both in quality and quantity in theelection. The smart house was to be the centre of electoral information by educating the public about the importance of elections and democracy, introducing basic values and democratic election (preselector), improving the importance of democracy for the entire segment and instilling the awareness of the democracy values. Smart home visits program was the best way to bring community groups. The smart home election providedaudience activity such as electoral film screenings, discussions/workshops/focus group discussions and seminars.

General Election Commission faced some problems in implementing political education to citizen, such as: [1] Face-to-face trainingis considered to be not effective because of the limited amount of time, participants, budget, location, and the lack of material and master instructor of political education. [2] Political education using mass media was constrained by budget, too much cost to the mass media. [3] Obstacles to distribute the object of socialization such as transportation facility and communication tools that make the goal of political education has not been achieved yet.

\section{Conclusion}

It can be concluded that the Political participation can be increased by providing political education to the public. The General Election Commission of West Sumatra has conducted socialization activities as parts of political education. Many obstacles needed to be solved such as; limited funds, location, the number of instructors was minimal. Many activities had been conducted by the election commission, but it has not been able to raise public awareness to participate in the election, especially the election of the Governor of West Sumatra. The researchers suggest that the government should be more concern about the low level of public participation to the election by providing serious and well-planned program of political education to the community.

\section{Recommendation}

Based on data analysis, this research can prove recommendation as follow:

1. The Province General Election Committee should improve socialization to public in order to give the voter well information about governor election.

2. The local government should do more education for facility to improve people awareness to participate in governor election.

\section{Acknowledgment}

The authors would like to thank to University of Bung Hatta, General Election Commissions Province of West Sumatera, proofreaders, and other individuals who has helped this research.

\section{References}

[1] Toni Ervianto. (2017).Election of Regional Head and Actual Problems, https://news.detik.com(published January 25, 2017)

[2] Ferree, E.K., Gibson, C.C. \& Long. (2014).Voting Behavior and Electoral Irregularities in Kenya's 2013 Election, Journal of Eastern 
African Studies, Vol 8 Iss1, pp 153-172. DOI. 10.1080/17531055.2013.871182.

[3] Fortin-Rittberger, (2014). The Role of Infrastructural and CoerciveStateCapacity inExplainingDifferent types of ElectoralFraud", Journal Democratization, Vol 21 I[1],pp. 95-117, DOI. 10.1080/13510347.2012.724064.

[4] Tsai-Wei Sun. (2015).Governing Singapore, Asian Education and Development Studies, Vol. 4 Iss 3 pp.282-298 DOI: 10.1108/AEDS-11-2014-0057.

[5] Saeed Ahmad, Mudasir Mustafa, Ahsan Ullah, Muhammad Shoaib, Muhammad Mushtaq and Wasif Ali. (2016).Role of types of electoral rigging, socio-economic status, politics and voting behavior in formation of attitude towards electoral integrity, Transforming Government: People, Process and Policy, DOI. 10.1108/TG-082015-0034.

[6] Collier, P. \& Vicente, C. P. (2012). Violence, bribery, and fraud: the political economy of elections in Sub-Saharan Africa. Public Choice, 153, 117-147. DOI. 10.1007/s11127-011-9777-z.

[7] Lehoucq, F. (2003). Electoral Fraud, Causes, Types, and Consequences. Annual Reviewof Political Science, 6,233-56. DOI. 10.1146/annurev.polisci.6.121901.085655.

[8] Chaturvedi, A. (2005). Rigging elections with violence. Public Choice, 125, 189-202.

[9] Biniecki, S.M.Y.and Conceigao, S.C.O. (2016). Using ConceptMaps to EngageAdultLearners in CriticalAnalysis, Adult Learning, Vol. 27 No.2, pp. 51-59, DOI $10.1177 / 1045159515604148$

[10] Vishal Arghode, Earl W. Brieger, Gary N. McLean, (2017) "Adult learning theories: implications foronline instruction", European Journal of Training and Development, Vol. 41 Issue: 7, pp.593609,DOI. 10.1108/EJTD-02-2017-0014

[11] Merriam, S.B.,Caffarella, R.S. and Baumgartner, L.M. (2007) Learning in Adulthood: A Comprehensive Guide, Jossey-Bass, San Francisco, CA.

[12] Rutherford-Hemming,T. (2012).SimulationMethodology in NursingEducation and AdultLearning Theory, Adult Learning, Vol. 23 No. 3, pp. 129-137, DOI.10.1177/1045159512452848.

[13] McLeod, G. (2003).Learning Theory and InstructionalDesign, Learning Matters, Vol. 2, pp. 35-43.

[14] Allen, S.J. (2007). Adult Learning Theory and LeadershipDevelopment, Leadership Review, Vol. 7,pp. 26-37

[15] Yilmaz, K. (2011). The cognitive perspective on learning: its theoretical underpinnings and implications for classroom practices:The Clearing House: A Journal of Educational Strategies, Issues and Ideas, Vol. 84 No. 5, pp. 204-212, DOI. 10.1080/ 00098655 2011.568989.

[16] Altman, B.A. (2009).Determining US workersTraining: history and constructivist paradigm, Journalof European Industrial Training, Vol. 33 No. 6, pp. 480-491, doi: DOI. 10.1108/03090590910974383.

[17] Jackson, L.D. (2009). Revisiting adult learning theory through the lens of an adult learner, Adult Learning,Vol.20No. 3, pp.20-22, DOI. 10.1177/104515950902000307.

[18] Arghode, V. (2013).Emotional and SocialIntelligenceCompetence:Implications for Instruction, International Journal of Pedagogies and Learning, Vol. 8 No. 2, pp. 66-77, DOI 10.5172/ijpl.2013.8.2.66

[19] Anderson,V.andGilmore, S. (2010).Learning, experienced emotions, relationships and innovation in HRD, Journal of European Industrial Training, Vol. 34 Nos 8/9, pp. 753-771, DOI. $10.1108 / 03090591011080959$

[20] Weibell, C.J. (2011).Principles of Learning: aConceptualFramework for Domain-SpecificTheories of Learning, dissertation Brigham Young University, Provo UT, June.

[21] Arghode, V.and Wang, J. (2016). Exploring TrainersEngagingInstructionalPractices:ACollectiveCaseStudy", European Journal of Training and Development, Vol. 40 No. 2, pp. 111-127, DOI. 10.1108/EJTD-04-2015-0033.

[22] Foote, L.S. (2015). Transformational Learning: Reflections of an AdultLearning Story, Adult Learning,Vol. 26 No. 2, pp. 84-86, DOI.10.1177/1045159515573017.

[23] Robert Holland. (2016). Participation and Engagement of PeopleWith a Learning Disability in the LeadUp to the 2015 GeneralElection, Tizard Learning Disability Review, Vol. 21 Iss 1 pp. 10 14. 